\title{
The Origin of Back-Arc Spreading in The Eastern Edge of Scotia Plate
}

\author{
Indra B Prasetyawan \\ Program Studi Oseanografi, Fakultas Perikanan dan Ilmu Kelautan, Universitas Diponegoro \\ Kampus Tembalang, Semarang 50275 Telp/Fax. 024-7474698 \\ Email : indrabudiprasetyawan2016@gmail.com
}

\begin{abstract}
The origin and evolution of back-arc spreading in the eastern edge of Scotia Plate will be discussed in this paper. The Scotia Plate is a tectonicplate on the edge of the South Atlantic and Southern Ocean, located between the South American and Antartic plates. The East Scotia Ridge (ESR) in the eastern edge of Scotia Plate, forned due to subduction of the South American plate beneath the South Sandwich plate along the South Sandwich Island arc. The methods and techniques of data acquisition used were data from absolution motions and data from magnetic anomalies and bathymetric data. Magnetic anomalies and bathymetric data that used in this paper consist of two sets data. First, magnetic anomalies and bathymetric data which were obtained by aboard HMS Endurance in the 1969-70 austral summer, and the second, magnetic anomalies and bathymetric data which were obtained after removal of the International Geomagnetic Reference Field (IGRF). Absolution motion analyses in the subduction zones of Sandwich plate results that form back-arc spreading in East Scotia Ridge showing high deformation for slow moving upper plates. Where back-arc spreading is associated with upper plate retreat that reaches $26.9 \mathrm{~mm} /$ year and have back-arc deformation style consistent with upper plate absolute.
\end{abstract}

Key Words: Geological oceanography, Scotia plate, back-arc spreading.

\begin{abstract}
Abstrak
Asal dan evolusi dari pemekaran back-arc di batas timur dari Lempeng Scotia akan dibahas di dalam artikel ini. Lempeng Scotia adalah lempeng tektonik di batas Atlantik selatan dan lautan selatan, yang berlokasi di antara Amerika Selatan dan Lempeng Antartik. Ridge Scotia timur di batas timur Lempeng Scotia terbentuk karena subduksi Lempeng Amerika Selatan di bawah Lempeng Sandwich Selatan sepanjang busur Pulau Sandwich Selatan. Metode dan teknik pengambilan data yang digunakan adalah data dari gerak absolusi dan data dari anomali magnetik dan data batimetri. Anomali magnetik dan data batimetri yang digunakan diperoleh dari HMS Endurancepada austral summer tahun 1960-70, dan yang kedua, anomali magnetik dan data batimetri yang diperoleh dari International Geomagnetic Reference Field (IGRF). Analisis gerak absolusidi czona subduksi dari Lempeng Sandwich menghasilkan bahwa pemekaran back-arc di Ridge Scotia Timur menunjukkan deformasi tinggi untuk gerakan lambat dari lempeng atas. Pemekaran back-arc ini berhubungan dengan mundurnya lempeng atas yang mencapai $26.9 \mathrm{~mm} /$ tahun dan memiliki gaya deformasi back-arc konsisten dengan gerak absolusi lempeng atas.
\end{abstract}

Kata kunci: Oseanografi geologi, Lempeng Scotia, pemekaran back-arc.

\section{Introduction}

The Scotia Plate is a tectonic plate on the edge of the South Atlantic and Southern Ocean. It is located between the South American and Antarctic plates. The eastern edge of the Scotia plate is a spreading ridge bounded by the South Sandwich microplate forming the East Scotia Ridge (ESR) (Thomas et al., 2003). The ESR is a back-arc spreading ridge that formed due to subduction of the

\footnotetext{
*) Corresponding author

http://ejournal.undip.ac.id/index.php/buloma

Diterima/Received : 15-01-2016

buloma.undip@gmail.com

Disetujui/Accepted : 27-03-2016
} 

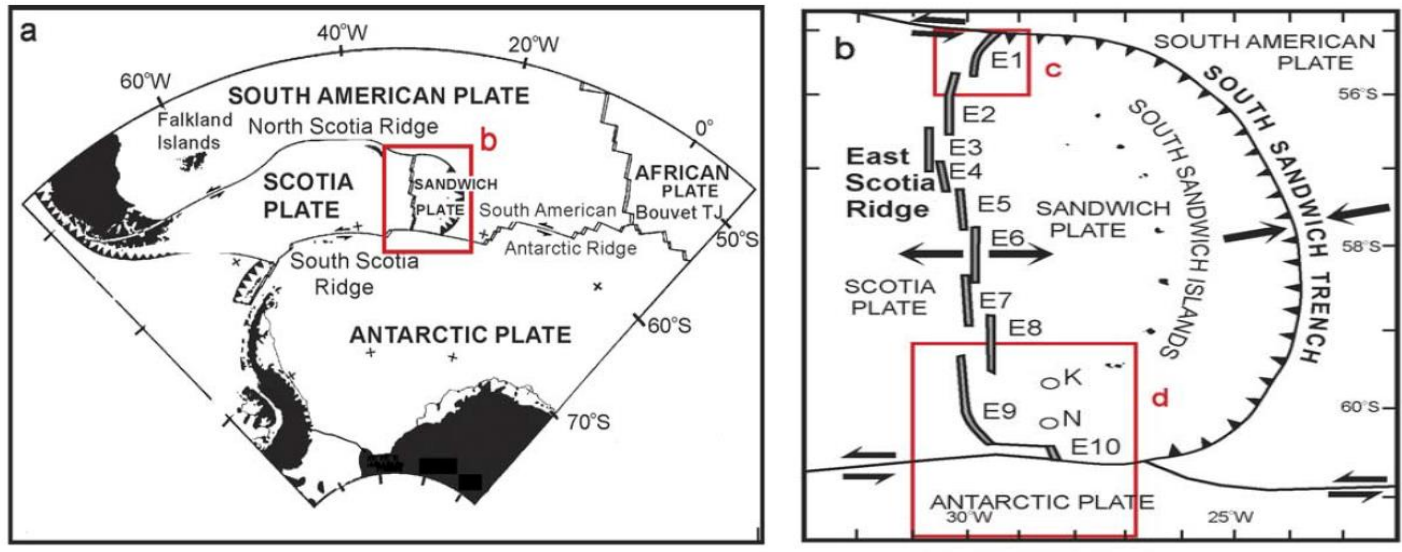

Fig. 1. Location of the East Scotia Ridge (ESR) in relation to the South American plate (SAM), the Antarctic plate (ANT), the Scotia plate (SCO) and the Sandwich plate (SAN). (a) Regional tectonic map. (b) Sketch map of the Sandwich Plate showing positions of segments of the back-arc spreading centre (E1 to E10) (Leat et al., 2004).

South American plate beneath the South Sandwich plate along the South Sandwich Island arc(Fig.1) (Livermore, 2003). It is considered to be one of the most isolated, yet simplest, examples of an activelyforming back-arc basin worldwide (Pelayo et al., 1989). Exact spreading rates of this back-arc are still being disputed in the literature, but it has been agreed that rates range between 60$90 \mathrm{~mm} / \mathrm{yr}$ (Livermore, 2003). Despite spreading was initiated more than $15 \mathrm{Ma}$, spreading in the south of the ridge began much more recently (estimated less than $3 \mathrm{Ma}$ ) (Bruguier et al., 2001). The spreading center consists of ten segments, from E1 inthe north, to E10 in the south (Fig.1) (Livermore et al., 1997).

The origin and evolution of this back-arc spreading will be discussed in this paper. The earliest attempts to explain back-arc deformation, and especially back-arc spreading, invoked mantle diapirism (Oxburgh et al., 1974) or secondary convection behind the arc (Sleep et al., 1971), but models of these types were unable to explain the observed variability of back-arc deformation. Examination of the role of various subduction parameters, and in particular those of plate kinematics such as upper plate and trench absolute motions, appeared relevant to back-arc deformation in earlier studies (Jarrard, 1986; Garfunkel et al., 1986; Otsuki, 1989). Explanations have been proposed for the presence of the arc and trench which describe the entire Scotia Sea as a fragment of Pacific crust, resisting the westward motion of Antarctica and South America (Hawkes, 1962; Wilson, 1966; Pichon, 1968). The phenomenon may be associated with back-arc spreading. Simply based on geometrical arguments, trenches and continents must move away from each other if the back-arc basins are actively spreading. It has been suggested that old oceanic lithosphere is gravitationally unstable, such that it will downfall under its own weight (Elsasser, 1971). As it downfalls and sinks downward, the trench will appear to migrate towards the ocean. This motion will generate a suction force which may be responsible for back-arc opening (Forsyth et al., 1975; Molnar et al., 1978).

\section{Geologic Setting}

Plate Motion on the Easternof Scotia Sea

The Scotia Sea represents a complex zone of microplates between two major plates, the South American and the Antartic. Bounded by subduction, spreading and transform ridges, the Scotia plate lies in a unique setting. The Scotia Sea is bounded on the east by the South Sandwich island arc, which has a westward-dipping subduction zone. The active back-arc spreading center is located in this eastern section of the Scotia Sea.Spreading along the ESR began approximately 20 Ma (Barker, 2001; Livermore, 2003), and the initiation of ESR divergence was associated with a decrease in spreading rate for the West Scotia Ridge. The full spreading rate in the West Scotia Ridge was 
approximately $48-52 \mathrm{~mm} / \mathrm{yr}$ from $26.5 \mathrm{Ma}$ to 17 Ma, but it decreased to about $20-24 \mathrm{~mm} / \mathrm{yr}$ from 17 Ma to 6Ma (Lagabrielle et al., 2009). The ESR replaced the West Scotia Ridge as the site of fastest spreading in the Scotia Sea at approximately $17 \mathrm{Ma}$ (Livermore, 2003).

\section{East Scotia Ridge}

The Scotia Ridge extends westward from the northern and southern ends of the South. Sandwich trench. The ESR is an active back-arc spreading center located to the west of the South Sandwich Island arc in the South Atlantic Ocean associated with subduction of the South American plate beneath the overriding Sandwich plate in the East Scotia Sea, Southern Ocean (Barker, 1970; German et al., 2000). It is currently extending at a full spreading-rate of $62-70 \mathrm{~mm} / \mathrm{yr}$, separating the Scotia Plate to the west from the much smaller Sandwich Plate, which extends no more than 300 $\mathrm{km}$ to the east. Despite its intermediate spreading rate, the ESR has an axial morphology more typical of a slow spreading ridge (Livermore et al., 1997; Leat et al., 2000; Larter et al., 2003). Although spreading was initiated more than $15 \mathrm{Ma}$, spreading in the south of the ridge began much more recently (probably less than $3 \mathrm{Ma}$ ) (Bruguier et al., 2001). Recent mapping has shown that the ESR composed ten segments (E1-E10) separated by a series of nontransform discontinuities. In segments E2 and E9 (Fig. 1) the spreading axis is characterised by smooth axial volcanic highs, similar to conventional fast spreading mid-ocean ridge morphologies. Similar features are not observed in the E3-E8 segments which, instead, show a well-developed deep rift-valley floor (Livermore et al., 1997).

\section{Methods and Techniques of data acquisition Absolution Motions}

To study the relative contribution of upper plate and trench motions to the back-arc deformation, these motions must be described in a fixed reference frame that is not attached to the plates, i.e., a terrestrial reference frame that gives each plate motion independently of mantle convection (Heuret et al., 2005).Several possible absolute reference frames exist, based on various assumptions. The most commonly used is the fixed hotspots reference. The hotspot dataset HS3 consists of volcanic propagation rates and sea mount segment trends from four plates. HS3-NUVEL1A, a set of angular velocities for 15 plates relative to hot spots and averaged for the last $5.7 \mathrm{M} / \mathrm{yr}$, was constructed from the HS3 data set while constraining the relative plate angular velocities to consistency withNUVEL-1A(Demets et al., 1994).

HS3-NUVEL1A absolute reference frame and for all the oceanic subduction zones, the motion of upper plates and trenches. The velocities are calculated at the trench, and seaward motion is defined as positive. For upperplates or trenches that moving away from the volcanic arc, the motion is defined as "retreat" and "advance" is used for motions directed toward the arc. For deformation rates, compression is defined as positive and extension as negative. To compare the different motions (Vup, $V \mathrm{t}$ and $V \mathrm{~d}$ ), these are projected along the trenchnormal azimuth.It is done because they are a more constant feature, trenches have been preferred to volcanic arc or back-arc deformation azimuths, which are sometimes used in other studies). $V u$ up(n), $V t(n)$ and $V \mathrm{~d}(\mathrm{n})$, respectively, refer to the trench normal $V u p, V t$ and $V d$ components (Heuret et al., 2005).

\section{Magnetic Anomalies and Bathymetric Data}

Magnetic anomalies and bathymetric data that used in this paper consist of two sets data. First, magnetic anomalies and bathymetric data which were obtained by aboard HMS Endurance in the 1969-70 austral summer, and the second, magnetic anomalies and bathymetric data which were obtained after removal of the International Geomagnetic Reference Field (IGRF) (Langel, 1992).

\section{Magnetic Anomalies and Bathymetric Data by Aboard HMS Endurance in the 1969-70 Austral Summer}

For the first data, the solid lines in figure 3.(a) are ship's tracks along which these data were measured. Along these tracks, the mean separation of good satellite fixes was $33 \mathrm{~km}$, and the maximum separation $200 \mathrm{~km}$. The tracks were intended to form two strip surveys of lines $15 \mathrm{~km}$ apart, running approximately east-west across the area occupied by the postulated spreading centre. International Geomagnetic Reference Field and an additional $200 \mathrm{nT}$ have been removed from the magnetic observations, but no attempt has been made to remove the diurnal variation (Barker, 1972). 
The echo soundings were corrected for variations in the speed of sound in sea water. Beneath the observed anomaly profiles in figure 3.(b) are drawn two computer-generated anomaly profiles, based on the Reversal Time Scale as modified by Talwani et al. (Heirtzler, et al., 1968; Talwani, et al., 1971). Model parameters include a source body thickness of $0.4 \mathrm{~km}$, an intensity of magnetisation varying smoothly between $700 \mathrm{nT}$ and $10 \mathrm{Ma}$ and $1500 \mathrm{nT}$ at $0.7 \mathrm{Ma}$,with a central block of double amplitude, and a depth to top in close agreement with the model of Sclater and Francheteau for the top of a $100 \mathrm{~km}$ thick oceanic lithosphere (Sclater et al., 1970; Talwani, et al., 1971). Also assumed were axially dipolar permanent magnetisation, negligible induced magnetisation, a present earth's field given by the IGRF and an anomaly strike of $010^{\circ}$. Spreading rates of $30 \mathrm{~mm} / \mathrm{yr} / \mathrm{side}$ (for the longer computed profile) and $15 \mathrm{~mm} / \mathrm{yr} / \mathrm{side}$ were used (Barker, 1972).

\section{Magnetic Anomalies and Bathymetric Data after Removal of the International Geomagnetic Reference Field (IGRF) 1992}

Magnetic anomalies in the East Scotia Sea have been related to east-west back-arc extension over the past 8 Ma (Barker, 1970; Barker, 1972; Barker et al., 1981).Data that used is the magnetic reversal time scale (MRTS) of Cande and Kent (1992), which is a significant improvement instead the previous generation in accuracy for determining the spreading rate and particularly the acceleration. Magnetic anomalies are displayed along track in Fig. 4.(b) after removal of the International Geomagnetic Reference Field (IGRF) (Langel, 1992). Ship tracks for all profiles are satellitepositioned (transit or GPS), mostly to better than 1.5 $\mathrm{km}$. There is no attempt has been made to eliminate the diurnal variation. Data were checked for magnetic storm influence before acceptance (Barker, 2004).

\section{Results}

\section{Absolution Motions}

Based on the hotspot dataset HS3 which consists of volcanic propagation rates and seamount segment trends from four plates for Sandwich subduction with Scotia upper plate gives results as shown in Table 1. Vup upper-normal component rates $(\operatorname{Vup}(\mathrm{n}))$ of Scotia upper plate are between 13.2 and $-26.9 \mathrm{mmy}^{-1}$, deformation-normal component rates $(V \mathrm{~d}(\mathrm{n}))$ are between -10.1 and $72.8 \mathrm{mmy}^{-1}$, trench-normal component rates $(V \mathrm{t}(\mathrm{n}))$ in the southern part have negative value between -1.9 and $-17 \mathrm{mmy}^{-1}$, and in the northern part have positive value between 8.5 and $49 \mathrm{mmy}^{-1}$. Cross-plot of back-arc deformation style versus trench normal component of upper plate absolute motion $(\operatorname{Vup}(\mathrm{n}))$ and versus normal to-the-trench component of trench absolute motion $(\mathrm{Vt}(\mathrm{n}))$ are shown in Fig. 2.(a) and (b).

\section{Magnetic Anomalies and Bathymetric Data}

Magnetic Anomalies and Bathymetric Data by Aboard HMS Endurance in the 1969-70 Austral Summer.

Correlations between anomalies on profiles AA' toFF' and their identification with anomalies on the $3.0 \mathrm{~cm} / \mathrm{yr}$ model profile are shown as dashed lines in figure 3.(c). Anomalies on the model profile, on $\mathrm{XX}^{\prime}$ in figure 3.(c) and identified anomalies are defined by their Lamont anomaly numbers (Heirtzler, 1968). Unidentified but correlated anomalies shown as alternate dashes and dots. Central through of bathymetric rough zone shown by thick dots, South Sandwich trench axis by open circles. $2000 \mathrm{~m}$ depth contour shown as solid line. Lettered tracks $\mathrm{AA}^{\prime}$ to $\mathrm{FF}^{\prime}$ and $\mathrm{XX}^{\prime}$ where $\mathrm{XX}^{\prime}$ is from Eltanin Cruise 8 (Barker, 1972). 
Table 1. Absolute upper plate and trench motions, back-arc deformation style and rate and slab age of all oceanic subduction zones (Heuret et al., 2005).

\begin{tabular}{|c|c|c|c|c|c|c|c|c|c|c|c|}
\hline Subduction name & $\begin{array}{l}\text { Latitude } \\
\text { (') }\end{array}$ & $\begin{array}{l}\text { Longitude } \\
\text { ( ) }\end{array}$ & Upper plate & References & $\begin{array}{l}\text { up(n) } \\
\left.\mathrm{mmy}^{-1}\right)\end{array}$ & Arc-block & erences & $\begin{array}{l}V_{\text {tn }} \\
\left(\mathrm{mm} \mathrm{y}^{-1}\right)\end{array}$ & $\begin{array}{l}V_{\mathrm{dn}} \\
\left(\mathrm{mmy}^{-1}\right)\end{array}$ & Df sup. & $\begin{array}{l}\text { Age } \\
\text { (My) }\end{array}$ \\
\hline \multirow[t]{6}{*}{ Sandwich (SAND) } & -60 & 335.4 & Scotia & Gripp and Gordon (2002) & 2) -15.7 & Sandwich Islands & Vanneste et al. (2002) & 17.9 & -33.7 & E3 & 33 \\
\hline & -58 & 336.2 & Scotia & Gripp and Gordon (2002) & 2) -24.4 & Sandwich Islands & Vanneste et al. (2002) & 49 & -72.8 & E3 & 36 \\
\hline & -56 & 334.9 & Scotia & Gripp and Gordon (2002) & 2) -26.9 & Sandwich Islands & Vanneste et al. (2002) & 39.4 & -62.1 & E3 & 40 \\
\hline & -55.1 & 333 & Scotia & Gripp and Gordon (2002) & 2) -20.8 & Sandwich Islands & Vanneste et al. (2002) & 8.5 & -28.8 & E3 & 40 \\
\hline & -54.9 & 331 & Scotia & Gripp and Gordon (2002) & -13.2 & Sandwich Islands & Vanneste et al. (2002) & -1.9 & -10.1 & E3 & 40 \\
\hline & -54.8 & 329 & Scotia & Gripp and Gordon (2002) & 2) -15.8 & Sandwich Islands & Vanneste et al. (2002) & -17 & - & E1 & 40 \\
\hline
\end{tabular}

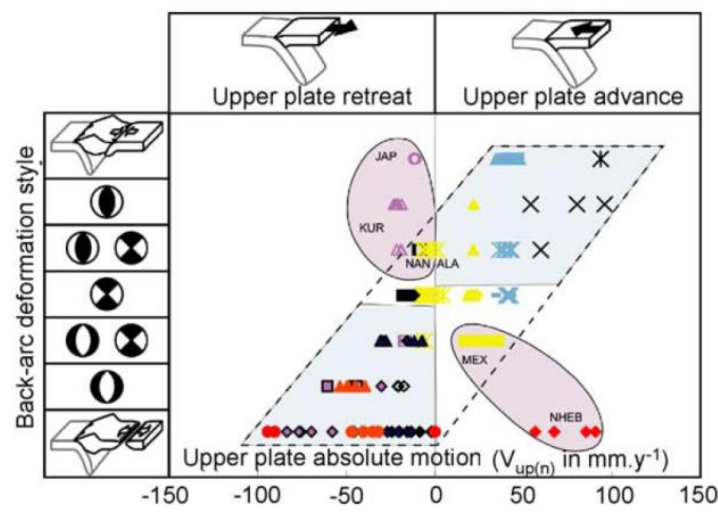

(a)

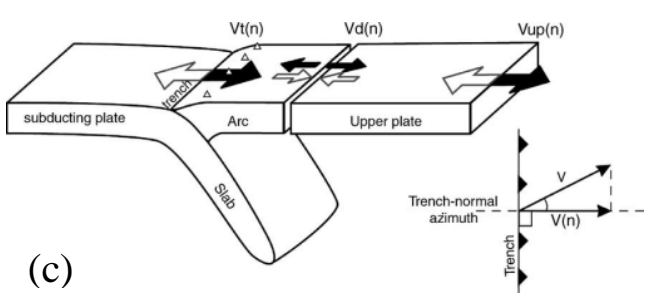

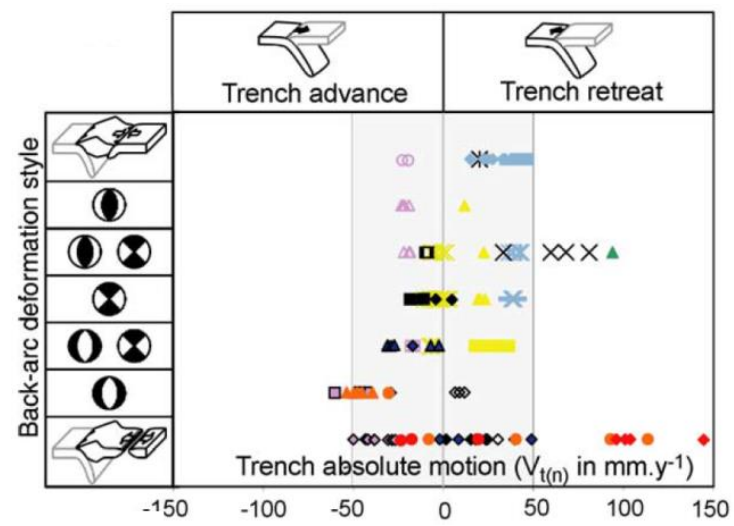

(b)

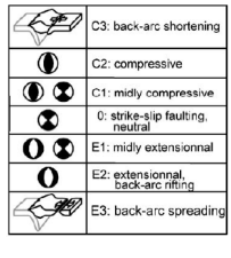

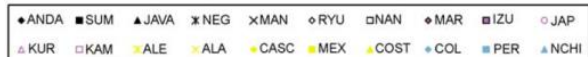
- JUAN XSCHI XTRI -PAT AANT •SAND $\triangle$ KER • TONG • NHEB •NBR

Fig. 2. (a). Cross-plot of back-arc deformation style versus trench normal component of upper plate absolute motion $(\operatorname{Vup}(n))$. (b). Cross-plot of back-arc deformation style versus normal to-the-trench component of trench absolute motion $(V \mathrm{t}(\mathrm{n}))$. (c). Structural pattern of subduction zones. Vup: upper plate absolute motion, $V \mathrm{t}$ : trench absolute motion, $V \mathrm{~d}$ : backarc deformation rate. Grey and black arrows, respectively, refer to positive and negative velocities, and trench-normal components of motion estimate (Vup, $V \mathrm{t}$ or $\mathrm{Vd}$ ). $V$ : rate; $V(\mathrm{n})$ : trench-normal component of rate (Heuret et al., 2005). 


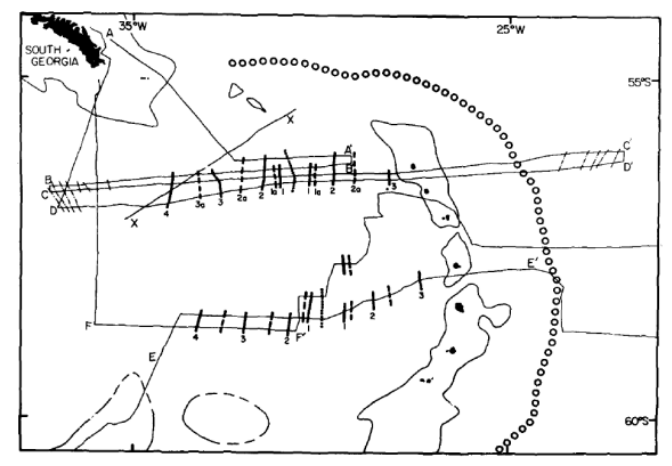

(a)

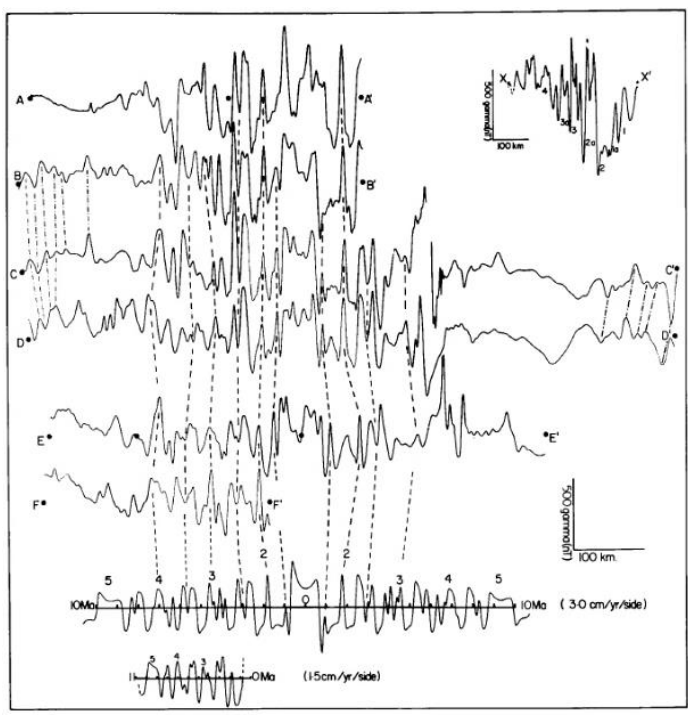

(c)
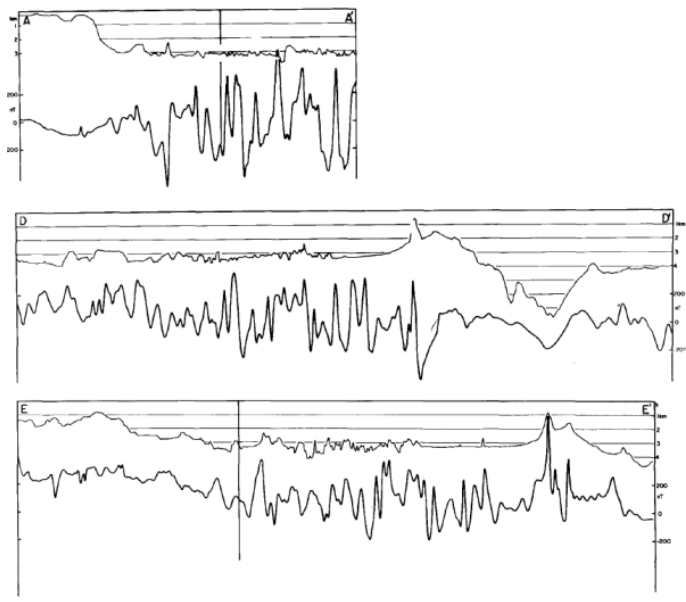

(b)

Fig. 3. (a). Track of H.M.S. Endurance in the east Scotia Sea, 1969-70. (b). Magnetic and bathymetric profiles along tracks $\mathrm{AA}^{\prime}, \mathrm{DD}^{\prime}$ and EE'.(c). Magnetic anomaly profiles along tracks $\mathrm{AA}^{\prime}$ to $\mathrm{FF}^{\prime}$ and $\mathrm{XX}^{\prime}$ and computed model anomaly profiles for spreading rates of 15 and 30mm/yr. Dashed lines show correlations and identification with Lamont-numbered anomalies (Barker, 1972). 
Magnetic Anomalies and Bathymetric Data after Removal of the International Geomagnetic Reference Field (IGRF) 1992.

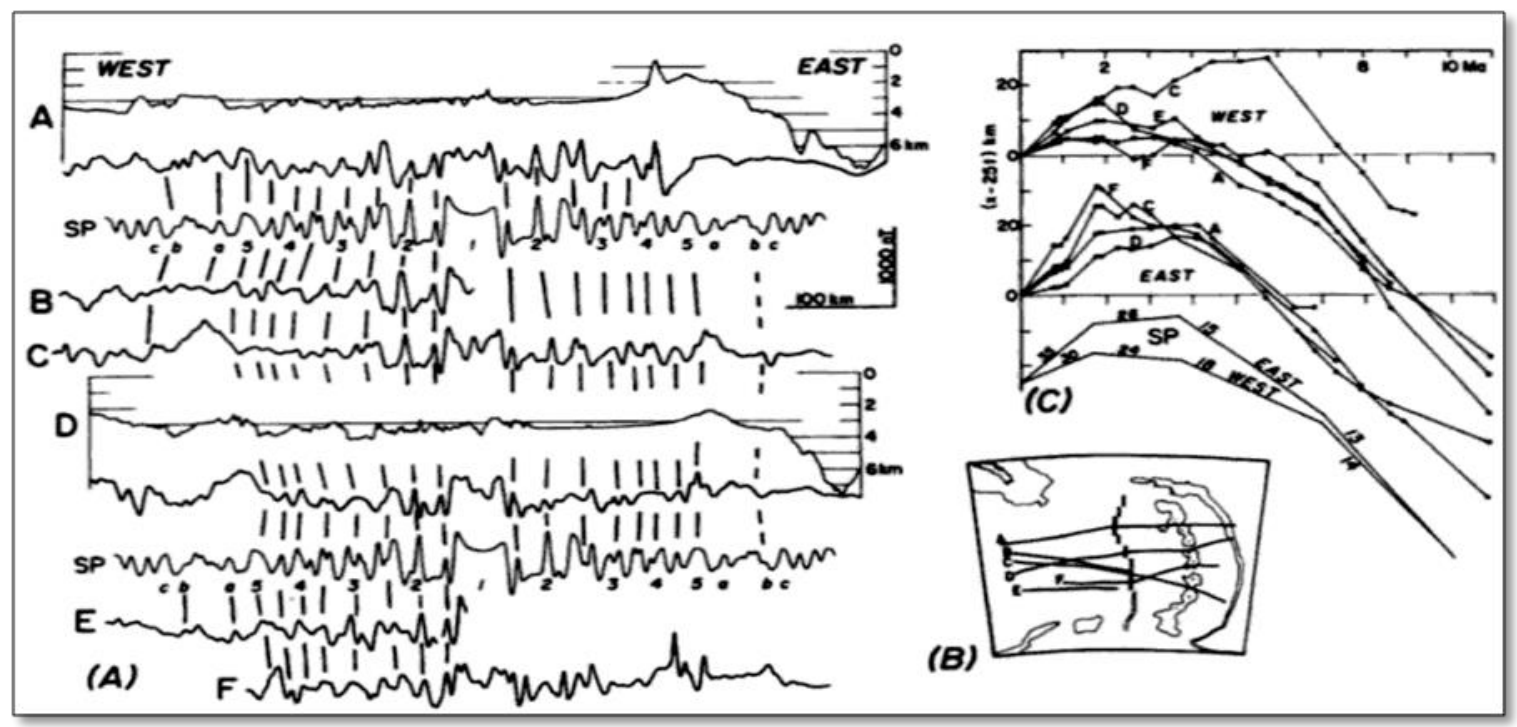

Fig. 4. (a). Magnetic profiles A to F (with bathymetry for A and D) crossing the East Scotia Sea, compared with a synthetic profile (SP) generated using the MRTS of Cande and Kent (1992). Located in (b). (c). Reduced distance plot to $25 \mathrm{~mm} /$ year (barker, 1979; Barke et al., 1981) of identified anomalies from the lettered profiled, and the set of spreading rates (SP) (Barker, 2004).

\section{Discussion}

\section{Absolution Motions}

In natural subduction systems (Fig. 2.(c)), the observed trench/slab migration velocity $V \mathrm{t}$, and upper plate deformation rate $V$ d, may result from a balance between the combination of all the forces that are able to drive trenches on the one hand (i.e., upper plate, buoyancy and mantle flow forces), and, the force that resist trench/slab migration on the other hand (Heuret et al., 2005).HS3-NUVEL1A gives the absolute motion for all major lithospheric plates and it can be used to describe the motion of subduction zone upper plate (Heuret et al., 2005). Based on a compilation of upper plate absolute motion, trench absolute motion, back-arc deformation rate and upper plate strain regime for Sandwich subduction zones we can examined how the combined effects of these parameters can account for the observed back-arc deformations. From cross-plot of back-arc deformation style versus trench normal component of upper plate absolute motion $(\operatorname{Vup}(\mathrm{n}))$ for Sandwich plate (SAN)
(Fig. 2.(a)) shows that subduction zones is on the fringe of the tendency, showing high deformation for slow moving upper plates. Where back-arc spreading is associated with upper plate retreat that reaches $26.9 \mathrm{~mm} /$ year. It is indicated by Vup uppernormal component rates (Vup(n)) of Scotia upper plate that are between -13.2 and $-26.9 \mathrm{~mm} /$ year.

From cross-plot of back-arc deformation style versus trench normal component of upper plate absolute motion ( $\operatorname{Vup}(\mathrm{n}))$ (Fig.2.(a)), in the Sandwich subduction zone where Scotia plate as upper plate and Sandwich Islands as arc-block (SAND), is in blue area. It indicates that subduction zones that have back-arc deformation style consistent with upper plate absolute motion (correspondence between back-arc extension and upper plate retreat and between back-arc compression and upper plate advance). And from cross-plot of back-arc deformation style versus normal to-the-trench component of trench absolute motion $(V \mathrm{t}(\mathrm{n}))$, the northern part of Sandwich subduction zone tends to trench retreat, nevertheless 
for the southern part tends to trench advance(Fig.2.(b)). Both of these are supported by the negative value of normal component of back-arc deformation rate $(V \mathrm{~d}(\mathrm{n}))$. The value of $V \mathrm{~d}(\mathrm{n})$ in the nothern part of back-arc tends to faster than in the southern part. It implies the spreading rate of the nothern part is faster than in the southern part.

\section{Magnetic Anomalies and Bathymetric Data}

From magnetic anomalies data which were obtained by aboard HMS endurance in the 1969-70 austral summer,the position of the centre of magnetic symmetry is obviously remarked on profiles BB', $\mathrm{CC}^{\prime}$ and $\mathrm{DD}^{\prime}$ and anomalies out to about $3 \mathrm{Ma}$ are attributable to east and west. The center of magnetic corresponds with a prominent trough in the zone of rough topography (dotted in Fig.3.(a)), as seen for profile DD' in Fig.3.(c), although this is not in the center of the rough zone because of the erasing effect of rapid sedimentation occurs in the east. Otherwise, on profile AA' the younger anomalies are not as would be expected, although anomalies 2 and $2 \mathrm{a}$ correlate well with those on other tracks. Also on AA', the bathymetric trough is displaced approximately westward and, as can be seen in Fig.3.(c), has asymmetric margins (Barker, 1972).

In the east, the magnetic anomalies caused by the South Sandwich Islands themselves make it unreasonable to say whether or not anomalies older than Lamont anomaly 3 occur on these profiles (see Fig.3.(c)), but in the west correlations have been made out to about 7.5 Ma. Between 3.5 and 7.5 Ma in the west, correlations are low; profile $\mathrm{BB}^{\prime}$ most closely features the $30 \mathrm{~mm} / \mathrm{yr}$ model, but $\mathrm{DD}^{\prime}$ is much more similar to a section of the $15 \mathrm{~mm} / \mathrm{yr}$ model, as are EE' and FF' of the southern survey. This latter similarity implies that before about 3.5 Ma the western side of the spreading centre was growing only at about $19 \mathrm{~mm} / \mathrm{yr}$. However, this alternative has been rejected on the evidence of XX' which shows clearly the anomalies between 3.5 and 7.5 Ma and whose obvious Lamont anomaly 4 coincides with the same anomaly on $\mathrm{CC}^{\prime}$ as identified by the $30 \mathrm{~mm} / \mathrm{yr}$ model. For the $15 \mathrm{~mm} / \mathrm{yr}$ model correlations to be correct, $\mathrm{XX}^{\prime}$ would have to have a positional error of about $60 \mathrm{~km}$ in that area, which is possible but unlikely (Barker, 1972).

Figure 4 shows a selection of magnetic and bathymetric profiles across the back-arc, arc, and fore arc with distance plot reduced to $25 \mathrm{~mm} /$ year (Barker, 1979; Barker et al.,1981) and a synthetic profile generated using the MRTS of Cande and Kent (1992). Since 1.7 Ma, the spreading has been fast, averaging about $65 \mathrm{~mm} /$ year over the full length of the back-arc. Then it was slower between 4 and $1.7 \mathrm{Ma}$, roughly $50 \mathrm{~mm} /$ year, and it was still slower before $5-7 \mathrm{Ma}$, less than $30 \mathrm{~mm} /$ year. Ocean floor produced during the past $3-4 \mathrm{Ma}$ tends to smoother than that produced earlier at lower spreading rates on most bathymetric profiles crossing the spreading center (Barker, 2004).

\section{Summary}

Absolution motion in the subduction zones of Sandwich plate that form back-arc spreading in East Scotia Ridge showing high deformation for slow moving upper plates. Where back-arc spreading is associated with upper plate retreat that reaches 26.9 $\mathrm{mm} /$ year and have back-arc deformation style consistent with upper plate absolute motion (correspondence between back-arc extension and upper plate retreat and between back-arc compression and upper plate advance). The northern part of Sandwich subduction zone tends to trench retreat, nevertheless for the southern part tends to trench advance. The spreading rate of the nothern part is faster than in the southern part. The magnetic anomalies data have confirmed generally that north and south active spreading center occurs to the west of the South Sandwich trench, and have admitted more accurate estimation to be made of spreading rate and directions. In the east Scotia Sea, plate growth at the spreading center and plate utilization at the trench are almost certainly required to be

\section{References Cited}

Barker, P.F., 1970, Plate tectonics of the Scotia Sea region, Nature, v. 228, p. 1293-1296.

Barker, P.F., 1972, A spreading centre in the East Scotia Sea. Earth and Planetary Science Letters, v. 15, p. 123-132.

Barker, P.F. and Hill, I.A., 1981, Back-arc extension in the Scotia Sea, Phil. Trans. R. Soc. London Ser. A, v. 300, p. 249-262. 
Barker, P.F., 2001, Scotia Sea regional tectonic evolution: implication for mantle flow and palaecirculation, Earth-Science Reviews, v. 55, p. 1-39.

Bruguier, N.J. and Livermore, R.A., 2001, Enhanced magma supply at the southern East Scotia Ridge : evidence for mantle flow around the subducting slab?, Earth and Planetary Science Letters, v. 191, p. 129144.

Barker, P.F., 2004, Tectonic framework of the East Scotia Sea, in Taylor, B. (Eds.), Bac-arc basins: tectonics and magmatism, Plenum Press, New York, p. 281-313.

Demets, C., Gordon, R.G., Argus, D.F., Stein, S., 1994, Effect of recent revisions to the geomagnetic reversal time scale on estimates of current plate motion. Geophys. Res. Lett., v. 21, p. 2191-2194.

Elsasser, W. M.,1971, Two-layer model of uppermantle circulation, J. Geophys. Res., v. 76(20), p. 4744-4753.

Forsyth, D.W. and Uyeda, S., 1975, On the relative importance of the driving forces of plate motion, Geophysis. J. Royal Astronomical Soc, v. 43, p. 163-200.

Garfunkel, Z., 1975, Growth, shrinking, and longterm evolution of plates and their implication for the flow pattern in the mantle, J. Geophysics. Res. v. 80, p. 44254432.

German, C.R., Livermore, R.A., Baker, E.T., Bruguier, N.I., Connelly, D.P., Cunningham, A.P., Morris, P., Rouse, I.P., Statham, P.J., Tyler, P.A., 2000, Hydrothermal plumes above the East ScotiA Ridge: an isolated high-latitude back-arc spreading centre, Earth and Planetary Science Letters, v. 184, p. 241250 .

Hawkes, D.D., 1962, The structure of the Scotia Arc, Geol Mag, v. 99,1, p. 85.
Heirtzler, J.R., Dickson, G.O., Herron, E,M., Pitmann III, W.C., Pichon, X.L., 1968, Marine magnetic anomalies, geomagnetic field reservals, and motions of the ocen floor and continents, J. Geophysics. Res. v. 73, 6, p. 2119.

Heuret, A. and Lallemand, S., 2005, Plate motions, slab dynamics nd back-arc deformation, Physics of the Earth and Planetary Interiors, v. 149, p. $31-51$.

Jarrard, R.D., 1986, Relations among subduction parameters, Rev Geophysics, v. 24, p. 217284.

Lagabrielle, Y., Godderis, Y., Donnadieu, Y., Malavielle, J., Suarez, M., 2009, The tectonic history of Drake Passage and its possible impacts on global climate, Earth and Planetary Science Letters, v. 279 (3-4), p. 197-211.

Langel, R.A., 1992, International geomagnetic reference field: The sixth generation, $J$. Geomagn. Geolectr., v. 44, p. 679-707.

Larter, R.D., Vanneste, L.E.,Morris, P.,Smythe, D.K., 2003. Structure and tectonic evolutionof the South Sandwich Arc. In: Larter, R.D., Leat, P.T. (Eds.), IntraOceanic Subduction Systems: Tectonic and Magmatic Processes. Geological Society, London, Special Publications,219, pp. 255284.

Leat, P.T., Livermore, R.A., Millar, I.L., Pearce, J.A., 2000, Magma supply in back-arc spreading centre segment E2, East Scotia Ridge, J. Petrol, v. 41, p. 845-866.

Livermore, R.A., Cunningham, A.P., Vanneste, L.E., Larter, R.D., 1997, Subduction influence on magma supply at the East Scotia Ridge, Earth and Planetary Science Letters, v. 150, p. 261-275.

Livermore, R.A., 2003, Back-arc spreading and mantle flow in the East Scotia Sea, in Larter, 
R.D. and Leat, P.T. (Eds.), Intra-oceanic subduction system: Tectonic and magmatic processes, Geol. Soc. London Spec. Publ., v. 219, p. 315-331.

Molnar, P. and Atwater, T., 1978, Interac spreading and cordilleran tectonics as alternates relate to the age of subducted oceanic lithosphere, Earth and Planetary Science Letters, v. 41, p. 330-340.

Oxburgh, R. and Turcotte, D., 1974, Origin of pained metamorphic belts and crustal dilation in islands arc regions, $\mathrm{J}$. Geophysics. Res. v. 76, p. 1325-1327.

Otsuki, K., 1989, Empirical relationships among the convergence rate of plates, rollback rate of rollback rate of trenchaxis and island-arc tectonics: laws of convergence rates of plates, Tectonophysics, v. 159, p. 73-94.

Pelayo, A.M. and Wiens, D.A., 1989, Seismotectonics and relative plate motions in the Scotia Sea region, J. Geophysics. Res. v. 86, p. 7293-7320.

Pichon, X.L., 1968, Sea-floor spreading and continental, J. Geophysics Res., v. 73,12, p. 3661 .

Sclater, J.G. and Francheteau, J., 1970, The implications of terrestrial heat flow observations on current tectonic and geochemical models of the crust and upper mantle of the earth, J. Geophysics, v. 20, p. 509.

Sleep, N. and Tokzos, M., 1971, Evolution of marginal basins, Nature, v. 33, p. 548-550.

Talwani, M, Windisch, C.C., Langseth, M.G., 1971, Reykjanes Ridge crest: A detailed geophysical study, J. Geophysics. Res. v. 76, 2, p. 473.

Thomas, C., Livermore, R.A., Pollitz, I., 2003, Motion of the Scotia Sea plates, J. Geophysics. Int. v. 155, p. 789-804.
Wilson, J.T. Are the structure of the Caribbean and Scotia Arc regions analogeous to ice rafting?, Earth and Planetary Science Letters, v. 1,4, p. 335. 